\title{
Utilization of Eco-friendly Bamboo Leaf Waste as Subgrade Stabilizer
}

\author{
Woelandari Fathonah $^{1 *}$, Rama Indera Kusuma ${ }^{1}$, Dwi Esti Intari ${ }^{1}$, \\ Eryani Siti Maryam ${ }^{1}$, Enden Mina ${ }^{1}$
}

Civil Engineering Department Universitas Sultan Ageng Tirtayasa Jendral Sudirman Street Km. 3, Cilegon, Banten

*Corresponding author. Email: woelandari@untirta.ac.id

\begin{abstract}
Soil has an important role in the construction of buildings and roads. Overall, the pavement must be strong enough to carry the weight of the vehicle on it. The strength of the road pavement depends on the bearing capacity of the subgrade. One of the efforts to increase the bearing capacity of the subgrade is to stabilize the original soil with bamboo leaf ash from burning residue. In this study, bamboo leaf ash was used to increase the bearing capacity of the soil. Bamboo trees have a high growth rate in Indonesia, one of which is in the Banten area, so that the waste from bamboo trees is feasible to be used as an eco-friendly additives. Variations of bamboo leaf ash used were 5\%, 10\%, and $15 \%$ of dry soil weight with curing time of 0 days, 3 days, and 7 days. The tests carried out in this study was the CBR test without immersion, testing the physical properties of the soil and soil classification based on USCS. The results showed that the addition of bamboo leaf ash to the soil decreased the plastic index value from $20.11 \%$ to $15.96 \%$ and could increase the CBR value from $3.4 \%$ to $13.31 \%$ at the optimum percentage of variations in ash from burning bamboo leaves. $\%$ and curing time is 7 days.
\end{abstract}

Keywords: Bamboo leaf, stabilizer, soil, CBR test

\section{INTRODUCTION}

The subgrade is the most important part of road construction and the soil layer is the most dominant in resisting construction loads. Every soil in each region has a different type of soil and ultimate bearing capacity [1]. One way to increase the bearing capacity of the subgrade is by stabilizing the soil with added materials, one of which is bamboo leaf ash. Soil stabilization is a method used to increase the bearing capacity of a soil layer, by giving special treatment to the soil layer [2]. One of the parameter to determine the bearing capacity of the soil is the CBR test. Subgrade soils with low soil bearing capacity have a low CBR value. The CBR method is used as a research method because the bearing capacity of the subgrade in road pavement planning is expressed by the CBR value. Jalan Kampung Ciherang, Pandeglang Regency was used as the location for soil sampling, because visually the highway was damaged, and based on the Dynamic Cone Penetrometer (DCP) test, the soil at that location had a bearing capacity of $2.8 \%$. In the design process for safety it must be assumed that the soil is saturated during the rainy season so that the DCP test results need to be multiplied by an adjustment factor of 0.90 . The minimum requirement for the bearing capacity of the subgrade according to the Bina Marga standard is $>6 \%$ [3]. Therefore, the subgrade at the study site needs to be stabilized. In this study, bamboo leaf waste was used, because bamboo leaf charcoal contains silica [4], while bamboo leaf ash from the furnace is a material that contains a lot of pozzolanic and high silica elements because it contains free lime elements that can harden with itself. Bamboo leaf ash contains silica (SiO2) of 75.90\% [5]. Indonesia is the third-largest bamboo producer in the world after China and India.

The area of bamboo forests in Indonesia in 2014 reached 2,058,000 hectares [9]. In the dry season, bamboo trees will shed some of their leaves to survive. For a bamboo forest area of $12,681.77 \mathrm{ha}$, it can produce around 11,412,900 bamboo sticks [10]. The data is used as a reference to predict the amount of bamboo leaf waste. The author estimates that a bamboo forest area of +1 ha can produce bamboo leaf waste of 0.528 tons/year, 
so for 2,058,000 ha of bamboo forest it is estimated that it can donate bamboo leaf waste of 1.08 million tons/year. So that waste from bamboo leaves can be used as subgrade stabilization material. Bamboo leaf ash can be used as a stabilizing material for laterite and soft soils in road construction [5-8].

\section{METHODS}

The initial stage of this research is to conduct a literature study and find information on the location to be studied. The second stage is to do a Location survey and Sampling of disturbed soil. The soil sample taken was clay soil taken from Jalan Kampung Ciherang, Pandeglang Regency. The stabilization material used is ash from burning bamboo leaves obtained from manual combustion. The process of making bamboo leaf ash from burning residue is done manually, namely by installing a space chimney made of ram wire that is shaped into a cylinder, then placing the chimney in the middle of the drum that has been filled with piles of dry bamboo leaves. This chimney serves to hold the outer bamboo leaves and to exchange air during the combustion process. The type of bamboo leaf used is apus bamboo (Gingantocchloa Apus). The next process is crushing the remaining burning bamboo leaves with a rubber hammer and filtered using filter no 50 . The filtering results obtained ash which was used as a subgrade stabilization material in this study. Ash from burning bamboo leaves and mixing native soil and bamboo leaf ash is shown in Figure 1.

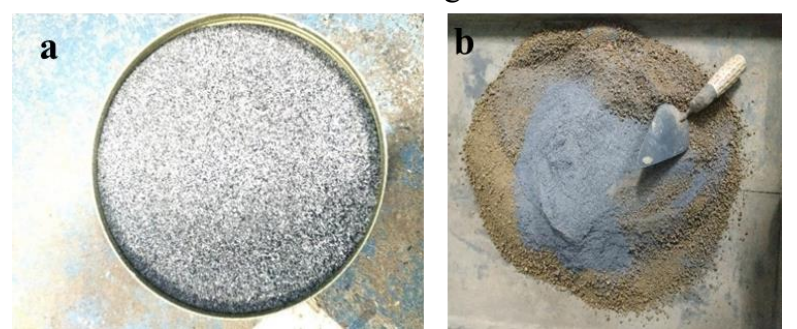

Figure 1. Mixture of soil and bamboo leaf ash: (a) Bamboo leaf ash; (b) Mixing native soil and bamboo leaf ash.

Variations of the mixture of bamboo leaf ash used were $5 \%, 10 \%$, and $15 \%$ of dry soil weight with curing time of 0 days, 3 days, and 7 days. Laboratory tests carried out include testing the physical properties of the soil including water content, liquid limit, plastic limit, specific gravity and filter analysis based on the applicable SNI [16], determining the classification of soil types based on USCS from the results of soil physical properties testing, Conducting soil compaction testing to get the value optimum water content and maximum dry density, then the soil is mixed with bamboo leaf ash with variations of $0 \%, 10 \%$ and $15 \%$ using the optimum water content obtained from soil compaction testing before mixing. The curing was carried out for 0 days, 3 days, and 7 days, using the following methods: mixing - curing - compaction - testing the California Bearing Ratio (CBR) unsoaked. Then do an analysis of the data that has been obtained from the testing phase, namely to find out whether bamboo leaf ash can be used as a subgrade stabilization material and compare the results of the original soil test with soil testing that has been mixed with bamboo leaf ash. The last stage is making conclusions based on the results of the research that has been done. The process of making test specimens and unsoaked CBR testing is shown in Figure 2.
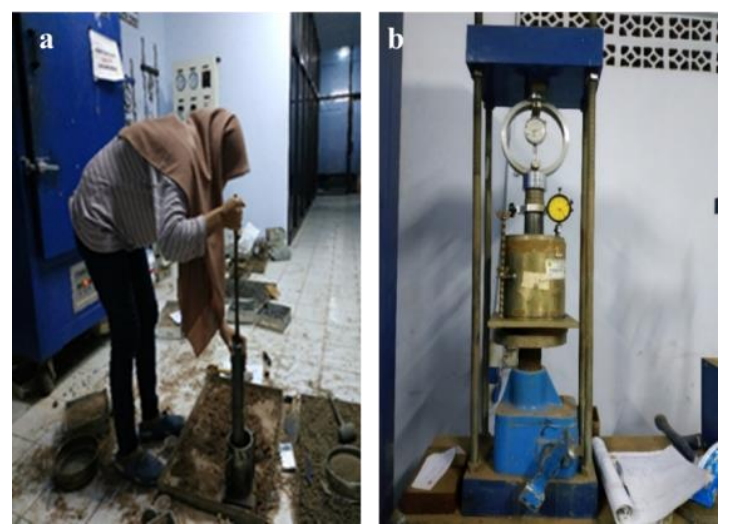

Figure 2. The process of making test specimens (a) and CBR test (b)

\section{RESULTS AND DISCUSSION}

Based on the tests that have been carried out, namely testing the soil properties consisting of the original soil water content, sieve analysis, Atterberg Limit, and the density data obtained, as shown in Table 1.

Table 1. Soil property test

\begin{tabular}{|c|l|c|c|}
\hline No & \multicolumn{1}{|c|}{ Test } & Unit & Result \\
\hline 1 & Water Content & $\%$ & 11.59 \\
\hline 2 & $\begin{array}{l}\text { Sieve Analysis, for soil } \\
\text { loose sieve no.200 }\end{array}$ & $\%$ & 64.90 \\
\hline 3 & Liquid Limit (LL) & $\%$ & 51.00 \\
\hline 4 & Plasticity Limil (PL) & $\%$ & 30.89 \\
\hline 5 & Plasticity Index (IP) & $\%$ & 20.11 \\
\hline 6 & Specific gravity (Gs) & - & 2.64 \\
\hline
\end{tabular}


From the results of the analysis of grain size analysis, liquid limit, and plastic limit from table 1 above, then adjusted to the USCS system table, the soil is classified as organic clay with high plasticity $(\mathrm{OH})[11]$. Bamboo leaf ash can reduce the plasticity index and increase the CBR value [5]'. Based on the standard proctor compaction test, the maximum dry density value was $1.375 \mathrm{~g} / \mathrm{cm}^{3}$ with an optimum moisture content of $33.00 \%$ as shown in Figure 3 below.

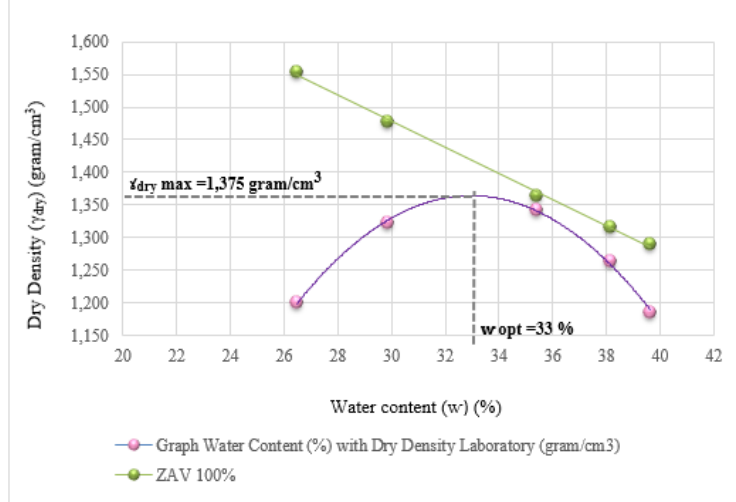

Figure 3 Relationship between soil dry density and water content

Figure 3 above shows a maximum dry weight of $1.375 \mathrm{gr} / \mathrm{cm}^{3}$ with an optimum moisture content of $33.00 \%$. The optimum moisture content and maximum dry density will be used for the calculation of the mixed material. Based on the results of the CBR test of unsoaked clay mixed with bamboo leaf ash with a percentage of $5 \%, 10 \%$, and $15 \%$, the curing time of 3 days and 7 days is shown in Figure 4 below.

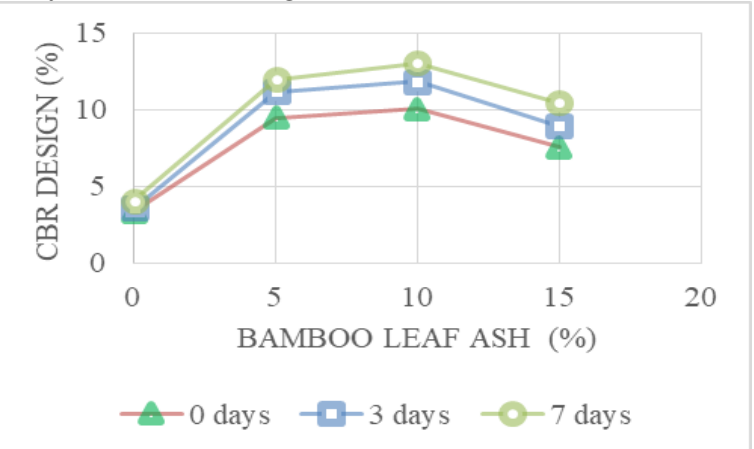

Figure 4. Relations of cbr value to bamboo leaf ash percentage

The CBR test is a relatively simple test which is commonly used to determine the value of the strength of the subgrade for use in road pavements [15]. Figure 4 shows the trend graph from the test results, namely the CBR value before stabilization was $3.4 \%$, and after stabilization it showed the highest increase in CBR value, namely $13.1 \%$ at $10 \%$ bamboo leaf ash percentage and 7 days curing time, meaning the CBR value increased by $385.3 \%$ from the CBR value before stabilization. The CBR value after being stabilized is in the category of meeting the criteria for a good score for road subgrade [12].

The effect of curing time on the CBR value with variations in the mixture of bamboo leaf ash is shown in Figure 5



Figure 5. Relation of CBR Value to Curing Time

Figure 5 shows the results that the longer curing time can increase the CBR value because the bond between the added material and the soil is getting stronger so that it can increase the CBR value. At $15 \%$ bamboo leaf ash percentage decreased, because this variation has almost the same ratio of the amount of ash to the soil due to the light weight of the ash so that the ash grains are more dominant when mixed with the soil which causes the bond between the soil grains to decrease and lowers the CBR value. The effect of adding bamboo leaf ash on the plasticity index value can be seen in Figure 6.

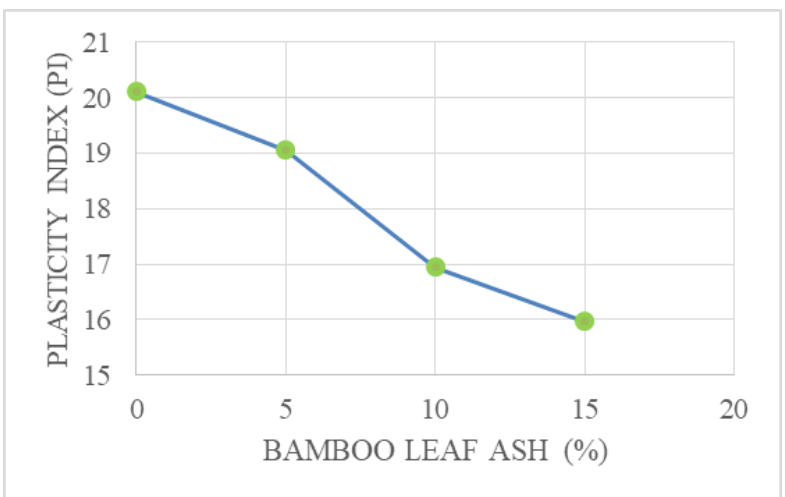

Figure 6. Relationship between plasticity index and mixed percentage 
Figure 6 shows the plasticity index value before stabilization was $20.11 \%$ and after stabilization showed a decrease in the plasticity index value of $15.96 \%$, meaning that the PI value decreased by $125.3 \%$ from the plasticity index value before stabilization. The plasticity index value $>17$ is included in the category of high plasticity index [14]. The value of the plasticity index after being stabilized is in the category of medium plasticity. The plasticity index decreased due to the nature of bamboo leaf ash filling the cavities in the soil so that the soil bonds became tenuous and could easily pass water [13].

\section{CONCLUSION}

The CBR value before stabilization was $3.4 \%$, and after stabilization with bamboo leaf ash showed the highest increase in CBR value, namely $13.1 \%$ at $10 \%$ bamboo leaf ash percentage and 7 days of curing time, meaning that the CBR value increased by $385.3 \%$ of the CBR value before stabilization. the plasticity index value before stabilization was $20.11 \%$ and after stabilization showed a decrease in the plasticity index value of $15.96 \%$, meaning that the plasticity index value decreased by $125.3 \%$ from the plasticity index value before stabilization. Overall it can be concluded that mixing origin soil with bamboo leaf ash from burning residue can increase the CBR value at a percentage of $10 \%$ bamboo leaf ash, but has not been able to significantly reduce the value of the soil plasticity index.

\section{ACKNOWLEDGMENT}

This research is supported by Sultan Ageng Tirtayasa University through an internal Research Grant Program in 2021.

\section{References}

[1] Fathonah W Intari D E Mina E \& Kusuma R I 2019 December Stabilization of clay using slag and fly ash with reference to UCT value (Case study: Jalan Kadusentar, Pandeglang District-Banten) In IOP Conference Series: Materials Science and Engineering Vol. 673 No. 1, p. 012038) IOP Publishing

[2] Panguriseng MSc Ir Daewis 2002 Stabilisasi Tanah (Universitas "45": Makassar)

[3] Kementrian Pekerjaan Umum 2017 Manual Desain Perkerasan Jalan Tahun 2017 (Direktorat Jen-deral Bina Marga: Jakarta)

[4] Saputro Y 2020 Kajian Partikel Abu sisa pembakaran Daun Bambu Tutul Hasil Tumbukan High Energy Ball Milling Tipe Shaker Mill Surya Teknika: Jurnal Ilmiah Teknik Mesin, 3(1)

[5] Amu O O \& Adetuberu A A 2010 Characteristics of bamboo leaf ash stabilization on lateritic soil in highway construction International journal of engineering and technology, 2(4), 212-219

[6] Rahman A S A Jais I B M Sidek N Ahmad J \& Rosli M I F 2018 April Bamboo leaf ash as the stabilizer for soft soil treatment. In IOP Con-ference Series: Earth and Environmental Sci-ence (Vol. 140, No. 1, p. 012068). IOP Publish-ing.

[7] Inim I J Affiah U E \& Eminue O O 2018 Assessment of bamboo leaf ash/lime-stabilized later-itic soils as construction materials Innovative Infrastructure Solutions, 3(1), 1-8.

[8] Iorliam A Y Agbede I O \& Joel M 2012 Effect of bamboo leaf ash on cement stabilization of Makurdi shale for use as flexible pavement construction material. American Journal of Scientific and Industrial Research, 3(3), 166-74.

[9] Abdullah Lutfy \& Priyanto 2014 Identifikasi dan Zonasi Kawasan Untuk Pengembangan Indus-tri Bambu di Bali (Fakultas Kehutanan IPB : Bogor)

[10] Yuliani N K Suka I G \& Pujaastawa I B G 2017 Bamboo Forest Conservation Based on Local Wisdom in Penglipuran Traditional Village Bangli District Bangli Regency Bali Province Jurnal Humanis, 18(1)

[11] Bowles J E \& Hainim J K 1984 Physical and geotechnical properties of soils (soil mechanics)

[12] Herawadi D Nursanto E \& Winarno E 2016 Technical Study on the Utilization of Fly Ash (Fly Ash) for PT Makmur Sejahtera Wisesa as the Base Laydown for PT Adaro Indonesia Jurnal Teknologi Technoscientia, 25-31

[13] Ramadhani T Iswan I \& Jafri M 2015 Relation-ship between Liquid Limit and Plasticity Index of Sand Substituted Clay on Soil Cohesion Values in Direct Shear Test Journal of Civil En-gineering and Design, 3(2), 291-302.

[14] Hardiyatmo H C 2006 Soil Mechanics 1 Fourth Edition Publisher Gadjah Mada University Press, Yogyakarta.

[15] Liu C \& Evett J B 1992 Soils and foundations Prentice Hall International.

[16] Badan Standarisasi Nasional 2008 SNI for soil testing 